\title{
An improved model of carbon and nutrient dynamics in the microbial food web in marine enclosures
}

\author{
J. G. Baretta-Bekker ${ }^{1, *}$, J. W. Baretta ${ }^{1}$, A. S. Hansen ${ }^{2}$, B. Riemann ${ }^{3}$ \\ ${ }^{1}$ Ecological Modelling Centre, Joint Department of Danish Hydraulic Institute and VKI, Agern Allé 5, \\ DK-2970 Hørsholm, Denmark \\ ${ }^{2}$ VKI, Agern Allé 11, DK-2970 Horsholm, Denmark \\ ${ }^{3}$ National Environmental Research Institute, PO Box 358, Frederiksborgvej 399, DK-4000 Roskilde, Denmark
}

\begin{abstract}
A description of an improved dynamic simulation model of a marine enclosure is given. New features in the model are the inclusion of picoalgae and mixotrophs; the ability of bacteria to take up dissolved inorganic nutrients directly; and, for the phytoplankton functional groups, the inclusion of luxury uptake and the decoupling of the nutrient uptake dynamics from carbon-assimilation dynamics. This last feature implies dynamically variable phosphorus/carbon and nitrogen/carbon ratios. The model was calibrated with experimental results from enclosure experiments carried out in Knebel Vig, a shallow microtidal land-locked fjord in Denmark, and verified with results from enclosure experiments in Hylsfjord, a deep and salinity-stratified Norwegian fjord. Both observations and model simulations showed dominance of a microbial food web in control enclosures with low productivity. In $\mathrm{N}$ and P-enriched enclosures a classical food web developed, while an intermediate system was found in $\mathrm{N}$-, P-and Si-enriched enclosures. Mixotrophic flagellates were most important in the nutrient-limited control enclosures where they accounted for $49 \%$ of the pigmented biomass and about $48 \%$ of the primary production. Lumping the mixotrophs in the simulation model with either the autotrophic or the heterotrophic functional groups reduced total primary production by $74 \%$. Model-derived, timeaveraged phosphorus budgets suggested that bacteria competed with algae for orthophosphate in the control enclosure, but not in the enclosure to which $\mathrm{N}$ and $\mathrm{P}$ had been added, where bacteria functioned as net mineralisers of phosphate. In the N, P and Si enclosure, bacteria took up only $10 \%$ of the amount of orthophosphate taken up by the primary producers, passing most of the organic phosphorus on to their grazers, the heterotrophic nanoflagellates, and mineralising only a small fraction directly. Inclusion of luxury nutrient uptake affected the simulation of the nutrient-enriched enclosures, while the decoupling of carbon and nutrient dynamics affected the simulation of the control enclosure. Without these 2 processes it was not possible to simulate the carbon and nutrient dynamics in the different enclosures adequately with the same parameterisation.
\end{abstract}

KEY WORDS: Microbial food web - Luxury uptake $\cdot$ Nutrient uptake Nutrient cycles $\cdot$ Ecosystem model $\cdot$ Mesocosm

\section{INTRODUCTION}

The construction of an ecological model able to adapt its internal channelling of the $\mathrm{C}, \mathrm{N}, \mathrm{P}$ and $\mathrm{Si}$ flows in the pelagic food web in response to perturbations in the availability and the partitioning of the nutrients is one of the holy grails in ecological modelling. However, as easy as it is to construct a conceptual

•E-mail: hbb@vki.dk model, making a dynamic simulation model that faithfully reproduces the shifting pathways of carbon and nutrients in the pelagic system while obeying the mass conservation law is a complex affair, especially as the bulk of the information on carbon and nutrient fluxes is indirect, in the form of biomass distributions and nutrient concentrations which by themselves are singularly uninformative with regard to the underlying fluxes, of which the standing stocks and concentrations are the end product. 
It is for these reasons that experimental setups and mesocosm experiments are invaluable for the testing and improvement of ecological models (BarettaBekker et al. 1994, Escaravage et al. 1995, 1996, Blackburn et al. 1996, Zweifel et al. 1996). Conclusions based on the results of the simulations of marine enclosures described by Baretta-Bekker et al. (1994) were that (1) the biological resolution of the model, with phytoplankton only comprising diatom and autotrophic flagellate functional groups, was too coarse, as it included neither a mixotrophic functional group nor picalgae (Baretta-Bekker et al. 1994) and (2) the use of Michaelis-Menten nutrient kinetics in the model, which does not allow for intracellular nutrient storage or luxury uptake of nutrients (Droop 1974, Nyholm 1977), was a probable cause of discrepancies between observed and model-predicted concentrations of nitrogen and phosphorus.

Mixotrophic nanoflagellates are commonly found in many different environments, and in some cases these pigmented organisms contribute significantly to the grazing of bacteria in lakes (Bird \& Kalff 1986, Bennett et al. 1990) and in coastal marine environments (Havskum \& Riemann 1996).

In recent years, the topic of mixotrophic nutrition in pelagic protists (flagellates and ciliates) has received increasing attention. In particular, the use of fluorescently labelled particles as tracers for uptake has improved the understanding of the role of phagotrophic phytoflagellates (Sanders 1991, Riemann et al 1995). The combination of autotrophic and heterotrophic nutrition in some protists provides an alternative route of material between microbial compartments in addition to the ones included in the more traditional concept of the microbial loop (e.g. Fenchel 1988).

The fact that mixotrophs do not rely on just 1 mode of nutrition gives them a competitive advantage, especially under limiting conditions (e.g. low light or low prey density), compared to strictly autotrophic or heterotrophic protists. The relative importance of the 2 nutrition modes, however, is largely unknown, since it tends to be species-specific and dependent on the environment (Sanders 1991). It has therefore been difficult to generalise the importance of mixotrophs and the factors controlling natural populations. $A$ s a consequence, there is a need for suitable models to predict the conditions under which mixotrophs may become significant (Riemann et al. 1995, Thingstad et al. 1996) and to examine their ecological role in microbial assemblages.

The complex structure of the marine planktonic food web allows for the dominance of strongly different components of the pelagic community in interaction with changes in the chemical and physical environment. Legendre \& Rassoulzadegan (1995) discerned a range of 4 different pathways in the marine planktonic food web, from dominance by the herbivorous web, coinciding with the classical food chain sensu Cushing (1989), through a multivorous web where microbial grazing is as significant as herbivorous grazing, to food webs increasingly dominated by grazing and recycling within the microbial components. In effect Legendre \& Rassoulzadegan (1995) proposed the existence of a generic pelagic food web with the different pathways expanding or contracting in response to modulations in the nutrient and light-energy supply.

In the present study the main objective was to improve the earlier model of mesocosm experiments described by Baretta-Bekker et al. (1994) into a model that is capable of predicting the time evolution of the biological constituents and the nutrient concentrations as observed in short-term mesocosm experiments by simulating the carbon and nutrient dynamics in nutrient-enriched as well as in nutrient-poor conditions.

The model described is based on a subset of the ERSEM model, version 11. An overview of ERSEM is given in Baretta et al. (1995). See Varela et al. (1995) and Ebenhöh et al. (1997) for descriptions of the primary production module, Baretta-Bekker et al. (1995) for the description of the microzooplankton module and Broekhuizen et al. (1995) for the mesozooplankton module.

The model runs in the software environment SESAME (Ruardij et al. 1995), on UNIX machines under Solaris. The conceptual time step is $1 \mathrm{~d}$, thus all rate parameters have the unit $d^{-1}$. SESAME uses adaptive time-stepping, reducing the time step whenever any rate of change exceeds 0.5 , thus minimising the numerical inaccuracy inherent in the used Eulerian integration method. The minimum value the time step can attain is set at $1 \times 10^{-6} \mathrm{~d}$, which is about $0.09 \mathrm{~s}$.

The model is calibrated with data from mesocosm experiments carried out in a small fjord in northeastern Denmark and verified with independent measurements from other mesocosm experiments carried out in the upper brackish layer of a fjord in southwestern Norway

\section{MATERIAL AND METHODS}

Mesocosm experiments. The model is calibrated with data from mesocosm experiments carried out in Knebel Vig, Denmark (56 $\left.14^{\prime} \mathrm{N}, 10^{\circ} 29^{\prime} \mathrm{E}\right)$, in the period from 26 June to 8 July 1994. Basically, the experiments, performed in cylindrical enclosures with a diameter of $1.75 \mathrm{~m}$ and a depth of $3 \mathrm{~m}$, are the same as those in 1991, described in Baretta-Bekker et al. (1994). The model was applied to 3 of the enclosures: 1 control and 2 of the nutrient-enriched ones, to which 
$\mathrm{N}$ and $\mathrm{P}$ or $\mathrm{N}, \mathrm{P}$ and $\mathrm{Si}$ had been added. Table 1 details the enrichment regimes. Initial values for the state variables were measured only in the control and were applied here to all 3 enclosures.

The model was validated with measurements from other mesocosm experiments carried out in the upper brackish layer of Hylsfjord $\left(59^{\circ} 30^{\prime} \mathrm{N}, 6^{\circ} 30^{\prime} \mathrm{E}\right)$, which is part of the Sandsfjord fjord system on the southwestern coast of Norway, in the period from 6 to 13 July 1995. Data were used from 4 enclosures which, with a diameter of $1 \mathrm{~m}$ and a depth of $2 \mathrm{~m}$, were somewhat smaller than those in Knebel Vig, enriched with nitrate, phosphate and glycine in different combinations according to Table 2. For a more detailed description of the experimental setup, see Havskum \& Hansen (1997).

The model. The model describes the carbon, phosphorus, nitrogen and silicon cycles in mesocosms which consist of a well-mixed water column, without sediment underneath. The model is physically forced by time series of daily irradiance and temperature as measured during the experiments. The biological constituents can be divided into the primary producers, the secondary producers and the decomposers, while in addition, mixotrophic flagellates are included as a state variable.

The non-biological state variables in the model are the nutrients phosphorus, nitrogen and silicate, oxygen, dissolved organic carbon, phosphorus and nitrogen and particulate carbon, phosphorus and nitrogen.

Fig 1 and Table 3 give an overview of the food web structure as incorporated in the model

Primary producers: The primary producers in the model consist of 3 functionally different groups, which are operationally defined as: (1) picoalgae, phytoplankton in the size class 0.2 to $2 \mu \mathrm{m}$ ESD (equivalent spherical diameter), grazed by heterotrophic nanoflagellates and mixotrophic flagellates; (2) autotrophic flagellates, mostly from 2 to $20 \mu \mathrm{m}$ ESD, grazed by heterotrophic nanoflagellates, mixotrophic flagellates, micro- and mesozooplanton; (3) diatoms, roughly from 20 to $200 \mu \mathrm{m}$ ESD, grazed by micro- and mesozooplankton. All groups are modelled in the same way and differ in the parameterisation only. An exception is the silicate dependence of diatoms. The standing stocks are described as densities of the carbon, nitrogen, phosphorus and, in the case of diatoms, silicate components of the biomass: Pc, Pn, Pp, Ps. Carbon is expressed in $\mathrm{mg} \mathrm{C} \mathrm{m}^{-3}$, while the nutrients are expressed in $\mathrm{mmol} \mathrm{m}^{-3}$.

In this model the inorganic carbon assimilation, i.e. the potential uptake, is dependent on the maximal uptake rate (sumP\$), irradiance, water temperature and, in the case of diatoms, on the external concentration of silicate. How much of the carbon assimilated
Table 1. Daily addition of nutrients in the form of inorganic nitrogen, phosphorus and silicate in $\mathrm{mmol} \mathrm{m}^{-3}$ to 2 enclosures in the Knebel Vig (Denmark) experiments, 1994

\begin{tabular}{|ccccccc|}
\hline \multirow{2}{*}{ Date } & \multicolumn{3}{c}{ N, P, Si enclosure } & \multicolumn{2}{c|}{ N, P enclosure } \\
& $N$ & P & Si & N & P \\
\hline 26 June & 14 & 2 & 14 & 14 & 2 \\
27 June & 14 & 2 & 14 & 14 & 2 \\
28 June & 14 & 2 & 14 & 14 & 2 \\
29 June & 14 & 2 & 14 & 14 & 2 \\
30 June & - & - & - & - & - \\
1 July & - & - & - & - & - \\
2 July & 7 & - & - & - & - \\
3 July & 35 & - & - & - & - \\
4 July & 14 & - & - & - & - \\
5 July & 14 & - & - & - & - \\
6 July & - & - & - & - & - \\
7 July & - & - & - & - & - \\
8 July & - & - & - & - & - \\
\hline
\end{tabular}

that can also be incorporated into biomass depends on the internal phosphorus and nitrogen pools. Thus gross productivity varies with the intracellular nutrient quota for phosphorus and for nitrogen. As the potential productivity, in periods of nutrient limitation, quickly exceeds the gross productivity, which is defined by the internal nutrient pool, high excretion rates of nutrientpoor dissolved organic carbon can occur. For diatoms the nutrient-stress lysis rate is not only based on the intracellular limitation of phosphorus and nitrogen, but also on the external silicate limitation. Net productivity is determined by how much carbon is respired, a process that in this model is independent of the internal nutrient pools.

The nutrient uptake processes for phosphate, ammonia and nitrate thus are decoupled from the carbon assimilation processes, with nutrient uptake being a function of the external nutrient concentration, the affinity of the phytoplankton group for a nutrient and the level of the intracellular nutrient storage.

For the silicate uptake (diatoms only) no storage is assumed, hence, assimilation of diatoms is additionally

Table 2. Daily additions of nutrients to the 4 enclosures of the Hylsfjord experiment in Norway, 6 to 13 July 1995. Addition of inorganic nitrogen, phosphorus and the $\mathrm{N}$ component of glycine in $\mathrm{mmol} \mathrm{m}^{-3}$ and the addition of the $\mathrm{C}$ component of glycine in $\mathrm{mg} \mathrm{C} \mathrm{m}^{-3}$

\begin{tabular}{|lcccc|}
\hline & N & NP & NG & NPG \\
\hline Nitrogen & 2 & 2 & - & - \\
Phosphorus & - & 0.1 & - & 0.1 \\
Glycine C & - & - & 48 & 48 \\
Glycine N & - & - & 2 & 2 \\
\hline
\end{tabular}



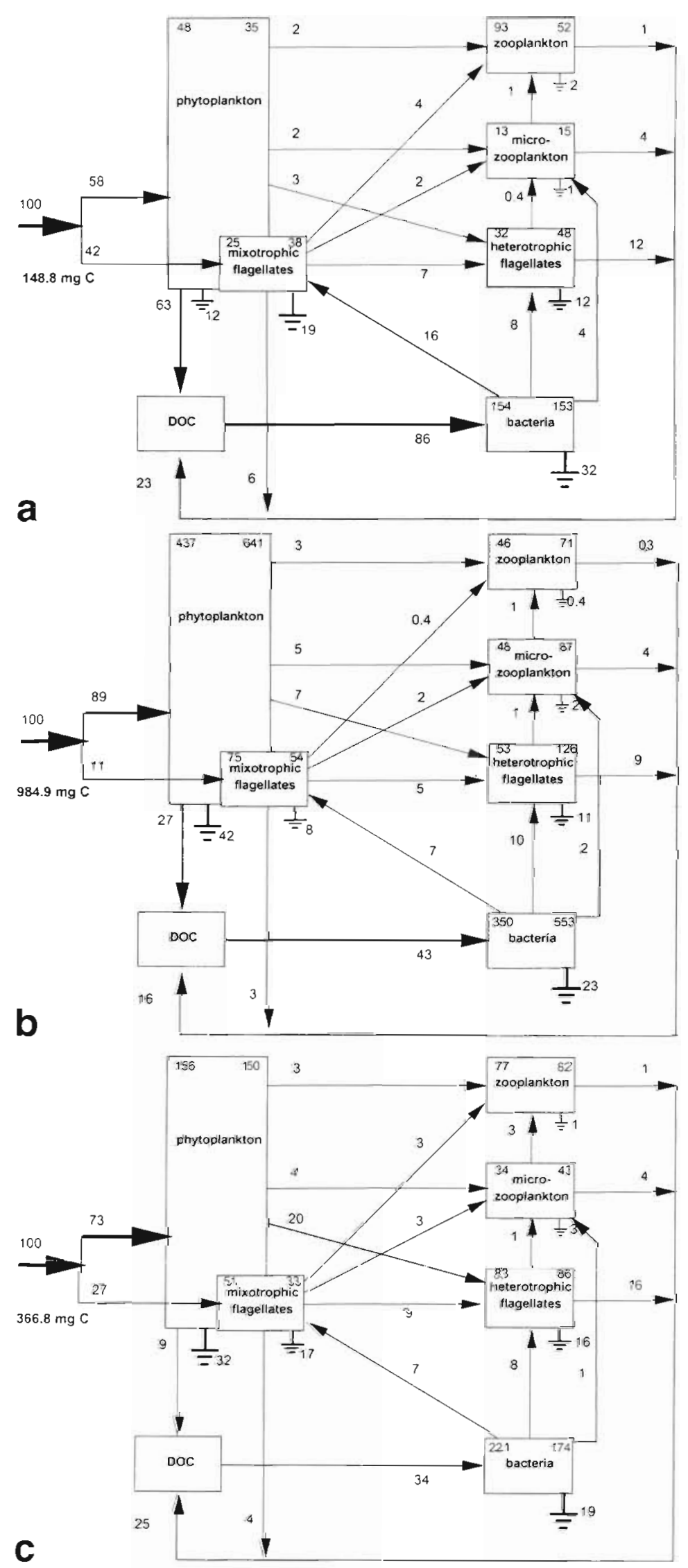

dependent on the external $\mathrm{SiO}_{4}$ concentration, and the Si uptake is proportional to carbon assimilation. In the case of negative net production (respiration exceeds production, in winter, on dark days and in deeper layers) nutrient release may occur. All processes are temperature dependent with the same $Q_{10}$ value.

In the previous version of the model (Baretta-Bekker et al. 1994, 1995) gross production was dependent on the external nutrient concentrations of $\mathrm{N}$ and $\mathrm{P}$, using classical Michaelis-Menten functions. As a consequence net productivity was always in step with external supply and excretion rates were low, as there could never be excess assimilate. In Table 4 the rates and their dependencies for both models are given.

A more extensive description of the decoupling of carbon and nutrient dynamics is given in Baretta-Bekker et al. (1997). Parameters used in the primary production module are given in Table 5.

Consumers: The consumers in this model consist of microzooplankton, heterotrophic flagellates and mesozooplankton. In Table 6 the parameters used in these modules are given.

Microzooplankton is defined as heterotrophic planktonic organisms from 20 to $200 \mu \mathrm{m}$ in size, excluding heterotrophic nanoflagellates, nauplii of mesozooplankton and benthic larvae. The microzooplankton consists mainly of suspension-feeding ciliates, which feed on phytoplankton, consisting of diatoms, autotrophic flagellates and picoalgae, on heterotrophic flagellates, bacteria and - because the microzooplankton itself is a large and diverse group - they also indulge in cannibalism. They are grazed by omnivorous mesozooplankton.

The heterotrophic flagellates feed on bacteria, on autotrophic phytoplankton, consisting of autotrophic flagellates and picoalgae,

Fig. 1. Normalised carbon flows through the system in (a) the control enclosure, (b) the N-, P- and Si-enriched enclosure and (c) the $\mathrm{N}$ - and Penriched enclosure. The calculated carbon flows are given as percentages of the daily average gross carbon assimilation of phytoplankton. Calculated average standing stocks are given in $\mathrm{mg} \mathrm{C} \mathrm{m}^{-3}$ and printed in the upper right corner of the boxes, with the experimentally derived values given in the left corner 
Table 3. Uptake/feeding relations as incorporated in the model. +: trophic interaction exists

\begin{tabular}{|c|c|c|c|c|c|c|c|c|c|}
\hline \multirow{2}{*}{ Substrate/prey } & \multirow[t]{2}{*}{ Code } & \multicolumn{3}{|c|}{ - Producers -} & \multirow{2}{*}{$\begin{array}{l}\text { Decomposers } \\
\text { B1 }\end{array}$} & \multicolumn{4}{|c|}{ - Consumers - } \\
\hline & & P1 & P2 & P3 & & P6 & Z6 & $\mathrm{Z5}$ & $\mathrm{Z} 4$ \\
\hline Diatoms & P1 & - & - & - & - & - & - & + & + \\
\hline Autotrophic flagellates & P2 & - & - & - & - & - & - & + & + \\
\hline Picoalgae & P3 & - & - & - & - & + & + & - & - \\
\hline Bacteria & B1 & - & - & - & - & + & + & - & - \\
\hline Mixotrophic flagellates & P6 & - & - & - & - & + & + & + & + \\
\hline Hetotrophic nanoflagellates & $\mathrm{Z} 6$ & - & - & - & - & + & + & + & - \\
\hline Microzooplankton & $\mathrm{Z} 5$ & - & - & - & - & - & - & + & + \\
\hline Mesozooplankton & $\mathrm{Z} 4$ & - & - & - & - & - & - & - & + \\
\hline Detritus & & - & - & - & + & - & - & - & + \\
\hline Phosphate & & + & + & + & + & + & - & - & - \\
\hline Nitrate & & + & + & + & - & + & - & - & - \\
\hline Ammonium & & + & + & + & + & + & - & - & - \\
\hline Silicate & & + & - & - & - & - & - & - & - \\
\hline
\end{tabular}

and on themselves. They are grazed in turn by microzooplankton and potentially by mesozooplankton.

Microzooplankton and the heterotrophic nanoflagellates are modelled according to the concept detailed in Baretta-Bekker et al. (1995), while mesozooplankton is modelled according to another concept, as described in
Broekhuizen et al. (1995). In this model only omnivorous zooplankton is distinguished. In order to effect a proper biomass of mesozooplankton over the short duration of the modelling experiment the measured biomass of the eggs produced was subtracted from the simulated mesozooplankton biomass, shunting the

Table 4. Specific rates determining the carbon dynamics in the model in comparison with the older version of the model. See Table 5 for explanation of the parameters. Bold-printed terms indicate nutrient limitation. All terms with Si refer to diatoms only and are printed in parentheses

\begin{tabular}{|c|c|c|}
\hline Specific rate & $\begin{array}{l}\text { Old model version } \\
\text { dependent on }\end{array}$ & $\begin{array}{l}\text { New model version } \\
\text { dependent on }\end{array}$ \\
\hline Max potential uptake & $\begin{array}{l}\text { sumPS } \\
\text { Temperature } \\
\text { Light } \\
\text { External nutrient concentration }\end{array}$ & $\begin{array}{l}\text { sumPS } \\
\text { Temperature } \\
\text { Light } \\
\text { (External Si concentration) }\end{array}$ \\
\hline Gross uptake & $\begin{array}{l}\text { Max. potential uptake } \\
\text { External nutrient concentration }\end{array}$ & $\begin{array}{l}\text { Max. potential uptake } \\
\text { Total excretion and lysis }\end{array}$ \\
\hline Lysis, nutrient stress & $\begin{array}{l}\text { Max, potential uptake } \\
\text { External nutrient concentration } \\
\text { pum_eoP\$ }\end{array}$ & $\begin{array}{l}\text { Internal nutrient pool } \\
\text { sdoP\$ } \\
\text { (External Si concentration) }\end{array}$ \\
\hline Excretion, nutrient stress & - & $\begin{array}{l}\text { Max. potential uptake } \\
\text { Internal nutrient pool } \\
\text { pu_eaP\$ }\end{array}$ \\
\hline Excretion, activity & $\begin{array}{l}\text { Max. potential uptake } \\
\text { pu_eaPS } \\
\text { External nutrient concentration }\end{array}$ & $\begin{array}{l}\text { Max. potential uptake } \\
\text { pu_eaP\$ }\end{array}$ \\
\hline Respiration, basal & $\begin{array}{l}\text { Temperature } \\
\text { srsP\$ } \\
\text { Fractional day length }\end{array}$ & $\begin{array}{l}\text { Temperature } \\
\text { srsP\$ }\end{array}$ \\
\hline Respiration, activity & $\begin{array}{l}\text { Gross uptake } \\
p u_{-} \text {raP\$ } \\
\text { External nutrient concentration }\end{array}$ & $\begin{array}{l}\text { Gross uptake } \\
\text { pu_raPS }\end{array}$ \\
\hline Respiration, nutrient stress & $\begin{array}{l}\text { Gross uptake } \\
\text { pum_roP\$ } \\
\text { External nutrient concentration }\end{array}$ & - \\
\hline
\end{tabular}


eggs produced to detrital carbon. Including the egg biomass into the mesozooplankton biomass would in effect mean that the egg biomass would have the same physiological rates as the rest of the mesozooplankton population. This would cause an unrealistically high grazing pressure.

Concerning the consumers in this model there is 1 essential change in comparison with the older version. The parameter minfood $\$$ acquired a different meaning. In the older model (Baretta-Bekker et al. 1994 1995) this parameter defined the threshold value of food concentration below which the heterotrophic nanoflagellates could not graze. In the model described in this study, minfood $\$$ is used in the microzooplankton and in the heterotrophic nanoflagellates module to apportion the food sources such that the grazers will eat relatively more from the more abundant sources, according to the following equation

$$
\text { rUST } T_{1} Z=\operatorname{suST}_{1-} Z \$ \cdot S T_{i} \cdot S T_{1} /\left(S T_{i}+\operatorname{minfood} \$\right)
$$

where $Z$ = consumers; $S T_{i}=$ state variable $i_{r}$ in this case a food source $i$ for $Z_{i} s u S T_{1} Z \mathbb{S}=$ parameter for the availability of $S T_{j}$ for $Z_{i} r u S T_{1} Z=$ uptake rate.

The nutrient dynamics in these groups is modelled as follows: at every timestep the excess of phosphorus and nitrogen relative to the fixed nutrient/carbon ratio, $q Z \Phi_{1}$ is excreted as inorganic phosphorus and as ammonium, respectively.

The carbon excretion products are taken to be organic carbon, partly in dissolved form and partly in particulate form, of which the dissolved form is available for bacteria at the same timestep.

Mixotrophic flagellates: The mixotrophic flagellates are defined as protists of a size between 2 and $20 \mu \mathrm{m}$ that are able to photosynthesise and feed heterotrophically at the same time. The model description of this group is a combination of the code for the primary producers and the code for heterotrophic nanoflagellates. Nutrient availability and food concentrations determine the degree to which they behave autotrophically or heterotrophically. They feed on bacteria, on picoalgae, on autotrophic and heterotrophic flagellates and on themselves.

With regard to the nutrient dynamics it is assumed that the mixotrophic flagellates can take up nutrients osmotrophically as well as phagotrophically. The excretion of nutrients is different from that of microzooplankton and heterotrophic nanoflagellates: in the calculation of the autotrophic phosphate uptake according to:

$$
\operatorname{run} P_{p}=\min (\operatorname{rum} 1 P p, \operatorname{rum} 2 P p)
$$

where rum $1 P p=\operatorname{run} P_{C} \cdot q p m P+(q p m P-q p P) \cdot P_{C}$

Table 5. Parameters of the primary producers and of the autotrophic part of the mixotrophic flagellates, as used in the model. P1: diatoms; P2: autotrophic flagellates; P3: picoalgae; P6: mixotrophic flagellates. Naming convention: P: one of the phytoplankton groups; $S$ : specifici $u$ : uptake; $r$ : respiration; $d$ : mortality; e: excretion; $g$ : grazing (when it is the second character) or gross (when it is the third character); $q$ : ratio; $t$ : total; $m$ : maximal $c_{1} n, p, s$ (as last character): carbon, nitrogen, phosphorus, silicate; $\$$ denotes

\begin{tabular}{|c|c|c|c|c|c|}
\hline State variable & & P1 & P2 & P3 & P6 \\
\hline \multicolumn{6}{|l|}{ Environmental effects } \\
\hline Characteristic $Q_{10}$ & $q 10 P \$$ & 2.0 & 2.0 & 2.0 & 2.0 \\
\hline \multicolumn{6}{|l|}{ Uptake } \\
\hline Max. specific uptake rate at $10^{\circ} \mathrm{C}$ & sumP\$ & 2.5 & 1.85 & 2.7 & 1.5 \\
\hline \multicolumn{6}{|l|}{ Loss rates } \\
\hline Excreted fraction of the uptake & $p u_{-} e a P \$$ & 0.05 & 0.05 & 0.05 & 0.05 \\
\hline Nutrient-lysis rate & $s d o P S$ & 0.01 & 0.01 & 0.01 & 0.01 \\
\hline \multicolumn{6}{|l|}{ Respiration } \\
\hline Rest respiration at $10^{\circ} \mathrm{C}$ & $\operatorname{srsPS}$ & 0.15 & 0.1 & 0.1 & 0.1 \\
\hline Activity respiration & $p u_{-} r a P \$$ & 0.4 & 0.4 & 0.4 & 0.4 \\
\hline \multicolumn{6}{|l|}{ Nutrient dynamics } \\
\hline Min. N/C ratio (mol g ${ }^{-1} \mathrm{C}$ ) & $q n I P \$$ & 0.00687 & 0.0687 & 0.00687 & 0.00687 \\
\hline Min. P/C ratio & $q p 1 P \$$ & $0.4288 \times 10^{-3}$ & $0.4288 \times 10^{-3}$ & $0.4288 \times 10^{-3}$ & $0.4288 \times 10^{-3}$ \\
\hline Redfield N/C ratio & $q \cap R P \$$ & 0.0126 & 0.01 .26 & 0.0126 & 0.0126 \\
\hline Redfield P/C ratio & $q p R P \$$ & $0.7862 \times 10^{-3}$ & $0.7862 \times 10^{-3}$ & $0.7862 \times 10^{-3}$ & $0.7862 \times 10^{-3}$ \\
\hline Multiplication factor max. N/C ratio & $x q \cap P \$$ & 2 & 2 & 2 & 2 \\
\hline Multiplication factor max. P/C ratio & $x q p P \$$ & 2 & 2 & 2 & 2 \\
\hline Max. Si /C ratio & $q S P C S$ & 0.03 & & & \\
\hline Affinity for $\mathrm{NO}_{3}$ & qurPn $3 \$$ & 0.005 & 0.005 & 0.0 & 0.0025 \\
\hline Affinity for $\mathrm{NH}_{4}$ & $q u P n 4 \$$ & 0.02 & 0.02 & 0.10 & 0.0025 \\
\hline Affinity for $P$ & qurPp\$ & 0.0025 & 0.0025 & 0.09 & 0.0025 \\
\hline Half value of $\mathrm{SiO}_{4}$ limitation & $\operatorname{chPS} \$$ & 1.0 & - & - & - \\
\hline
\end{tabular}
a parameter 
Table 6. Parameters of the microzooplankton functional groups, of the bacteria and of the heterotrophic part of the mixotrophic flagellates, as used in the MEICE model. ST stands for state variable and can be substituted by one of the following: Z5: microzooplankton; Z6: heterotrophic flagellates; P6: mixotrophic flagellates; B1. bacteria. Other symbols and naming convention as in Table 5

\begin{tabular}{|c|c|c|c|c|c|}
\hline Parameter & & 25 & Z6 & P6 & B 1 \\
\hline \multicolumn{6}{|l|}{ Environmental effects } \\
\hline Characteristic $Q_{10}$ & q10ST\$ & 2.0 & 2.0 & 2.0 & 2.95 \\
\hline Half oxygen saturation & chrSToS & 7.8125 & 7.8125 & 7.8125 & 7.8125 \\
\hline \multicolumn{6}{|l|}{ Uptake } \\
\hline Half saturation value & chuSTCS & 80 & 300 & 300 & - \\
\hline Max specific uptake rate $10^{\circ} \mathrm{C}$ & sumSTS & 1.2 & 7.0 & 7.0 & 8.38 \\
\hline Availability of $\mathrm{P} 1$ for $\mathrm{ST}$ & suP1_STS & 0.1 & - & - & - \\
\hline Availability of $\mathrm{P} 2$ for ST & SUP2_STS & 1.0 & 0.5 & 0.0 & - \\
\hline Availability of P3 for ST & SUP3_STS & 0 & 1.0 & 1.0 & - \\
\hline Availability of $\mathrm{P} 6$ for ST & SUP6_STS & 1.0 & 0.5 & 0.0 & - \\
\hline Availability of Z5 for ST & SUZ5_STS & 1.0 & - & - & - \\
\hline Availability of Z6 for ST & SUZ6_STS & 0.2 & 0.2 & 0.0 & - \\
\hline Availability of B1 for ST & SUB1_STS & 0.1 & 0.1 & 0.1 & - \\
\hline Selectivity & minfoodSTS & 200 & 100 & 100 & - \\
\hline \multicolumn{6}{|l|}{ Loss rates } \\
\hline Assimilation efficiency & puST\$ & 0.5 & 0.25 & 0.4 & 0.5 \\
\hline Assimilation efficiency at low temperature & puSTo\$ & - & - & - & 0.2 \\
\hline Excreted fraction of uptake & pu_eaSTS & 0.5 & 0.5 & 0.5 & - \\
\hline \multicolumn{6}{|l|}{ Excretion } \\
\hline Fraction of excretion production to DOM & $p e_{-} R 1 S T \$$ & 0.5 & 0.5 & 0.5 & - \\
\hline \multicolumn{6}{|l|}{ Mortality } \\
\hline Oxygen-dependent mortality rate & sdSTO\$ & 0.25 & 0.25 & 0.25 & - \\
\hline Temperature-independent mortality & sdSTS & 0.05 & 0.05 & 0.05 & 0.0 \\
\hline \multicolumn{6}{|l|}{ Respiration } \\
\hline Rest respiration at $10^{\circ} \mathrm{C}$ & $\operatorname{srsSTS}$ & 0.02 & 0.02 & 0.02 & 0.01 \\
\hline \multicolumn{6}{|l|}{ Nutrient dynamics } \\
\hline Max. N/C ratio & $q n S T_{C} \$$ & 0.0167 & 0.0167 & 0.0167 & 0.02084 \\
\hline Max. P/C ratio & $q p S T C \$$ & 0.00185 & 0.00185 & 0.00185 & 0.002083 \\
\hline \multicolumn{6}{|l|}{ Other parameters } \\
\hline $\mathrm{C} / \mathrm{N}$ ratio in fresh detritus (Redfield ratio) & $p R 6 c R 6 n \$$ & 6.625 & & & \\
\hline Temperature dependency & q10N4N3S & 2.367 & & & \\
\hline Relative nitrification rates & sN $4 n 3 \$$ & 0.01 & & & \\
\hline
\end{tabular}

and $\quad \operatorname{rum} 2 P p=q u P p \$ \cdot P O_{4} \cdot P C$

the term $(q p m P-q p P) \cdot P c$ can become negative if $q p P>q p m P$. In that case there is a negative phosphate uptake, which is in fact a phosphate release. Nitrogen excretion is treated identically. The nitrogen released is added to the pool of $\mathrm{NH}_{4}$.

Bacterioplankton: Bacteria take up dissolved organic matter (DOM) at the same timestep as DOM is produced. Depending on the amount of nutrients in this DOM the bacteria will either take up or excrete nutrients. The actual intracellular nutrient/carbon ratio determines the size and the direction of the nutrient flux. If the difference between the actual nutrient/carbon ratio $q B 1$ and the maximum value $q B 1 \$$ is positive, the bacteria will excrete nutrients. When the difference is negative they will take up inorganic nutrients, limited by a Michaelis-Menten ratio, according to the following formulae: if

$(q p B 1 c-q p B 1 C \$)>0$

then

else

release $=(q p B 1 C-q p B 1 C \$) \cdot B 1 C$

uptake $=(q p B 1 c \$-q p B 1 c) \cdot B 1 c \cdot P O_{4} /\left(P O_{4}+c h B 1 p \$\right)$

In the model the functional group of bacteria includes picobacteria and a population of filamentous bacteria, which was observed during the experiments in increasing numbers (Havskum pers. comm.). Because ciliates can prey on filamentous bacteria (Havskum \& Hansen 1997), the food web structure has been adapted so that the bacteria can be eaten by microzooplankton.

Apart from the ability to take up inorganic nutrients and the change in the food web interactions the formulation is the same as described in Baretta-Bekker et al. (1995). 


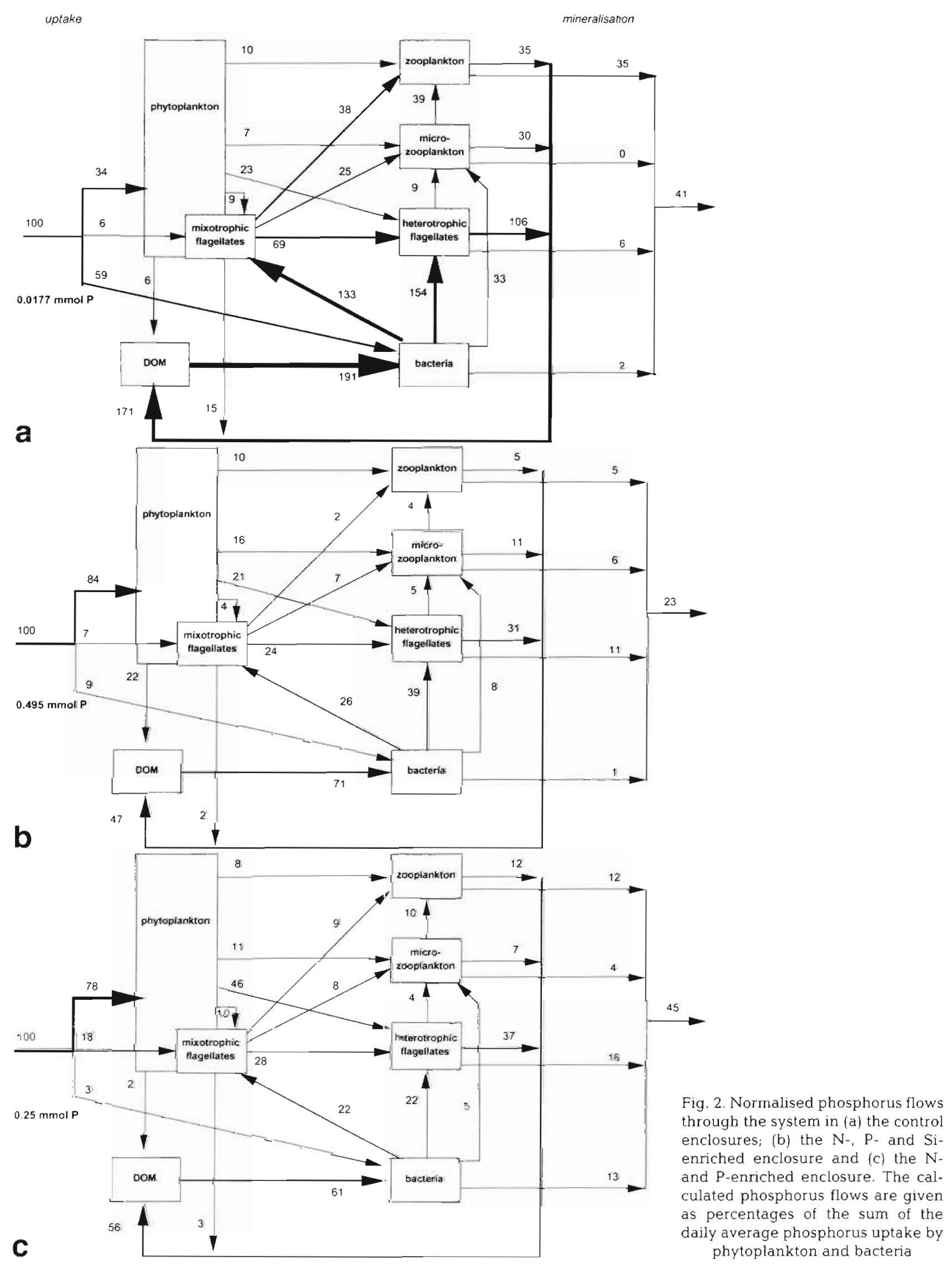


Table 7. Turnover times for phosphorus in h for each enclosure, calculated with the standard version of the model and measured (Thingstad unpubl. data)

\begin{tabular}{|c|c|c|c|c|c|c|}
\hline \multirow[t]{2}{*}{ Date } & \multicolumn{2}{|c|}{ Control } & \multicolumn{2}{|c|}{ N-, P-, Si-enriched } & \multicolumn{2}{|c|}{ N-, P-enriched } \\
\hline & Data & Model & Data & Model & Data & Model \\
\hline 27 June & 18.6 & 56.9 & - & 84.0 & - & 90.3 \\
\hline 28 June & 18.6 & 28.9 & 44 & 323.6 & 5.1 & 297.6 \\
\hline 30 June & 3.85 & 9.1 & 9.5 & 439.5 & 5.8 & 286.7 \\
\hline 2 July & 2.86 & 7.0 & 13.7 & 427.7 & 3.4 & 121.9 \\
\hline 4 July & 4.38 & 7.0 & 3.2 & 625.9 & 5.7 & 296.4 \\
\hline
\end{tabular}

\section{RESULTS}

The preferred method of calibrating and verifying a model with data of several experimental setups is to use the data of one of the setups for calibration and those of the other enclosures for validation (Jørgensen 1995). Because the objective was to make the model formulation as generic as possible, because each of the mesocosms evolves in a different direction and none of them is in steady state, we considered it more important to arrive at 1 parameter set that was able to reproduce the different experiments qualitatively, instead of parameterising for a quantitative reproduction of 1 particular experiment.

As will be clear from the model-derived budgets of carbon and phosphorus (Figs. $1 \& 2$ ) for the 3 enclosures, different processes dominated in each enclosure, implying that the sensitivity of the model to particular parameters should be different in each case. For example, in a condition of nutrient enrichment, the parameters defining incipient nutrient limitation cannot be calibrated, as nutrient limitation does not play a role there. Therefore all 3 enclosures were used in calibrating the model, and data of mesocosm experiments carried out in the summer of 1995 in Norway were used for the validation (Havskum \& Hansen 1997).

Except for standing stocks, nutrient concentrations and those fluxes that could be compared directly to measurements, turnover times for phosphorus and nitrogen were also used to calibrate the model. The turnover time $t_{p}$ (Table 7 ) is expressed in hours and defined as:

$$
t_{p}=24 /\left(\operatorname{runPTp} / \mathrm{PO}_{4}\right)
$$

where runPTp is the total amount of phosphorus taken up daily by the phytoplankton groups and bacterioplankton, and $\mathrm{PO}_{4}$ is the concentration of phosphorus. In the same way the turnover times $t_{n}$ for nitrogen $\left(\mathrm{NO}_{3}+\mathrm{NH}_{4}\right)$ can be calculated.

\section{Control enclosure}

Model results together with measurements of standing stocks and some of the fluxes are given in Figs. $3 \mathrm{a}-\mathrm{d}$ to $6 \mathrm{a}-\mathrm{d}$. The model reproduced the time evolution of the standing stocks of diatoms and autotrophic flagellates in the control enclosure quite well (Fig. $3 \mathrm{a}$, b). The simulated biomass of the smaller picoalgae (Fig. 3c), however, did not reach the observed levels and not the right time evolution. Of all the loss fluxes from picoalgae calculated in the model, measurements for 2 of the grazing fluxes were available: the flux to the mixotrophic flagellates and the flux to heterotrophic flagellates (Fig. $4 \mathrm{a}$, b). The simulated flux to the heterotrophic flagellates was overestimated in the beginning, but was correct in the second part of the experiment, while the simulated flux to the mixotrophs did not have the right form. The simulation of the mixotroph biomass (Fig. 3d) was of the right order of magnitude, but failed in the time evolution. The bacterial biomass (Fig. 5a) was also of the right order, while the flux from bacteria to mixotrophic flagellates (Fig. 4c) was too high and to
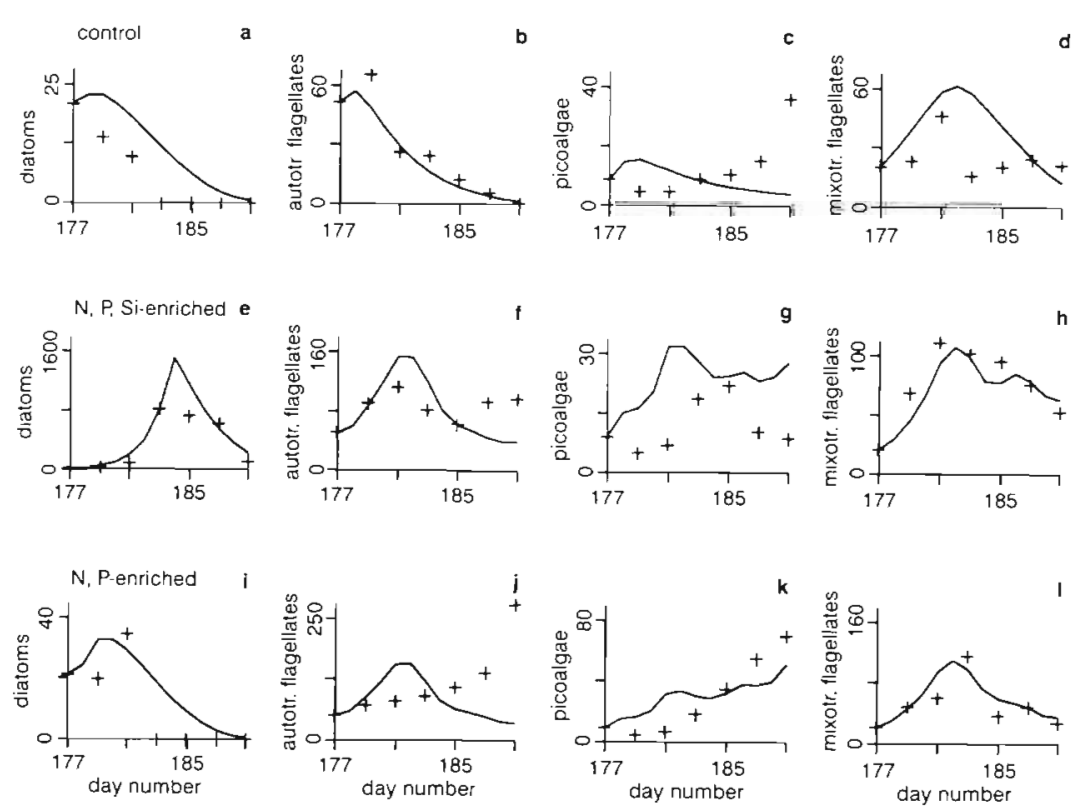

Fig. 3. Simulation output and measurements of standing stocks in $\mathrm{mg} \mathrm{C} \mathrm{m} \mathrm{m}^{-3}$ of the primary producers and of the mixotrophic flagellates in (a to d) the control enclosure, (e to h) the N-, P- and Si-enriched enclosure and ( $\mathrm{i}$ to $\mathrm{l}$ ) the $\mathrm{N}$ - and $\mathrm{P}$ enriched enclosure 
heterotrophic nanoflagellates too low (Fig. 4d) Because this was similar to the picoalgal fluxes (Fig, $4 \mathrm{a}, \mathrm{b}$ ), it indicates that the position and the role of the mixotrophs in this oligotrophic situation, especially with regard to their interactions with the heterotrophic nanoflagellates and bacteria, are not completely captured by the model. The time evolution of heterotrophic flagellates, micro- and mesozooplankton (Fig. 5b-d) and the nutrient concentrations (Fig. 6a-d) was reproduced correctly, although at the end of the experiment the silicate concentration remained higher than the measurements. This indicates that the nutrient uptake and regeneration processes in toto were captured correctly, that the balance between autotrophs, heterotrophs and decomposers in the nutrient cycling was correct, but that the grazing interactions in the microbial food web between the mixotrophic and heterotrophic flagellates, the picoalgae and the bacteria were not fully resolved.

The model-derived carbon flows in the control enclosure are given in Fig. 1a. The fluxes are expressed as percentages of the total gross primary production by phytoplankton and the mixotrophic flagellates. The major carbon fluxes were the flux from phytoplankton into DOC at $63 \%$, followed by the excretion/lysis fluxes from the heterotrophic components at $23 \%$, together $86 \%$ of the primary production. This DOC was quickly recycled by bacteria, indicating the central role of the bacterioplankton which respired half this flux back into $\mathrm{CO}_{2}$ again, while the heterotrophic nanoflagellates and mixotrophs recovered the other half through grazing on the bacterioplankton. The transfer fluxes into microzooplankton and mesozooplankton from both phytoplankton and nanoflagellates were all less than $10 \%$.

The phosphorus flows in the control were normalised to the sum of the phosphorus uptake fluxes by phytoplankton, mixotrophic flagellates and bacteria (Fig. 2a). The DOM excreted by the primary producers was nutrient-poor, leading to a direct inorganic nutrient uptake by bacteria (Fig. 2a), which exceeded that of the phytoplankton, but was quickly regenerated, mainly by the heterotrophic nanoflagellates and the mesozooplankton.

\section{N-, P- and Si-enriched enclosure}

Model results and measurements from the $\mathrm{N}$-, P- and $\mathrm{Si}$-enriched enclosure are given in Figs. $3 \mathrm{e}-\mathrm{h}$ to $6 \mathrm{e}-\mathrm{h}$. The model failed to reproduce the observed time evolution of the $\mathrm{N}_{-}, \mathrm{P}$ - and Si-enriched enclosure without an extra lysis rate dependent on the external silicate concentration. From the measurements it was clear that halfway through the experiment, around $1 \mathrm{July}$, 'something' happened in the N,P and Si enclosure. Although there was still silicate (Fig. 6h) the diatom biomass (Fig. 3e) stopped increasing. The nitrate concentration (Fig, 6f) on that day was very low (1.17 $\left.\mathrm{mmol} \mathrm{m}^{-3}\right)$. From 2 July nitrogen was added again which caused a small biomass increase for autotrophic flagellates, but not for the diatoms. Grazing by mesozooplankton, roughly calculated to be $35 \mathrm{mg} \mathrm{C}$ $\mathrm{m}^{-3}$ on 2 July, or other grazing processes, was insufficient to explain the collapse of the diatom biomass.

The diatom biomass ( $F i g .3 e$ ) in the model increased somewhat too long as nutrient limitation occurred only later. Thereafter Si limitation caused a strong decline in biomass. The autotronhic flagellates (Fig. 3f) were underpredicted in the second part of the experiment. The picoalgae (Fig. 3g) were slightly overpredicted. The mixotrophs (Fig. 3h) and the bacteria (Fig. 5e) were simulated correctly by the model. The grazing fluxes on bacteria predicted by the model (Fig. $4 \mathrm{~g}$, h) were of the right order of magnitude, but did not reproduce the time variability in the observations. Both

Fig. 4. Simulation output and measurements of fluxes in $\mathrm{mg} \mathrm{C} \mathrm{m}^{-3} \mathrm{~d}^{-1}$ from the bacteria and from the picoalgae to the heterotrophic nanoflagellates and to the mixotrophic flagellates in (a to d) the control enclosure, (e to h) the $\mathrm{N}$-, $\mathrm{P}$ - and $\mathrm{Si}$ enriched enclosure and (i to l) the $\mathrm{N}$ - and P-enriched enclosure 

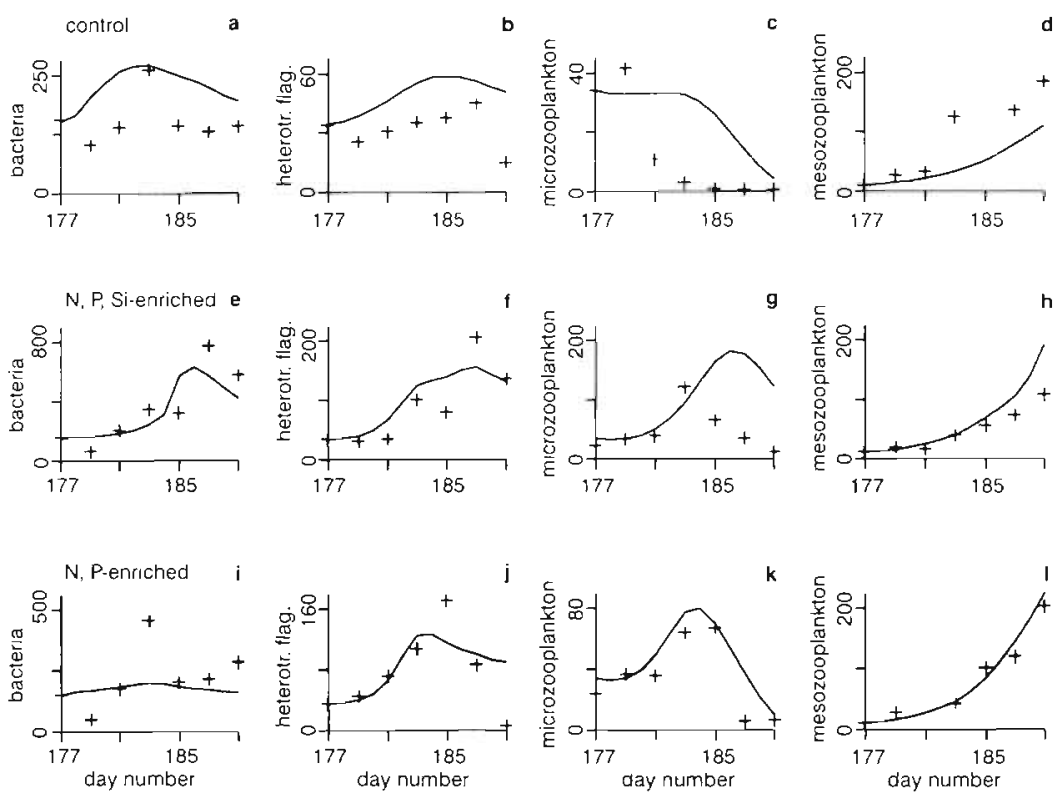

Fig. 5. Simulation output and measurements of the standing stocks in $\mathrm{mg} \mathrm{C} \mathrm{m}{ }^{-3}$ of the bacteria, the consumers and the mixotrophic flagellates in (a to d) the control enclosure, (e to h) the N-, P- and Si-enriched enclosure and (i to l) the N-and P-enriched enclosure

micro- and mesozooplankton standing stocks (Fig. 5g, h) were overpredicted in the second half of the experiment.

The simulated nutrient concentrations (Fig. 6e-h) were very close to the measurements, except for the last few days, when the modelled concentrations remained higher than the measured ones.

\section{$\mathrm{N}$ - and P-enriched enclosure}

Figs. $3 \mathrm{i}-1$ to $6 \mathrm{i}-1$ give the simulated functional group biomasses, some of the fluxes and the nutrient concentrations with the measured values. Although the prediction of both particulate and dissolved primary production was much lower than the measurements (not shown), the time evolution of the standing stocks of the primary producers (Fig. 3i, k) was reproduced correctly, except for the autotrophic flagellates (Fig. 3j), which were not in accordance with the measurements. This is the same discrepancy as was appearing in the $\mathrm{N}-, \mathrm{P}-$ and Sienriched enclosure. The mixotrophic flagellates (Fig. 31), the microzooplankton (Fig. 5k) and the mesozooplankton (Fig. 51) were simulated cor-
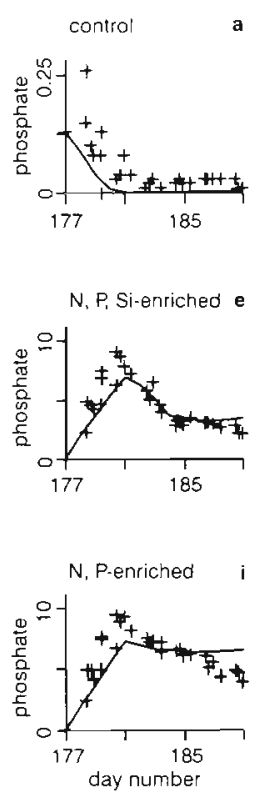

rectly, as well as the simulated fluxes. Here again nitrate, phosphate (Fig. 6i, j) and ammonium (Fig. 6k; data: $\mathrm{H}$. Kaas pers. comm.) were overpredicted towards the end of the simulation. The carbon fluxes (Fig. 1c) were quite different from those in the control (Fig. 1a). According to the model most of the assimilated carbon went directly from the primary producers to the consumers, where the heterotrophic nanoflagellates occupied a key position, generating $43 \%$ of the incoming carbon into DOC, producing almost half of the total DOC formed. All the DOC produced was consumed by bacteria, providing food for mixotrophic and heterotrophic flagellates. From the heterotrophic nanoflagellates only a small fraction was channelled to higher trophic levels.

Fig. 2c, with the phosphate fluxes, shows that the dissolved organic matter flux from the consumers contained sufficient phosphorus for the bacteria not to take up orthophosphate. In this situation the bacteria and the primary producers did not compete for nutrients, but bacteria regenerated nutrients from dissolved organic matter. The budgets indicated the phosphate storage in bacteria.
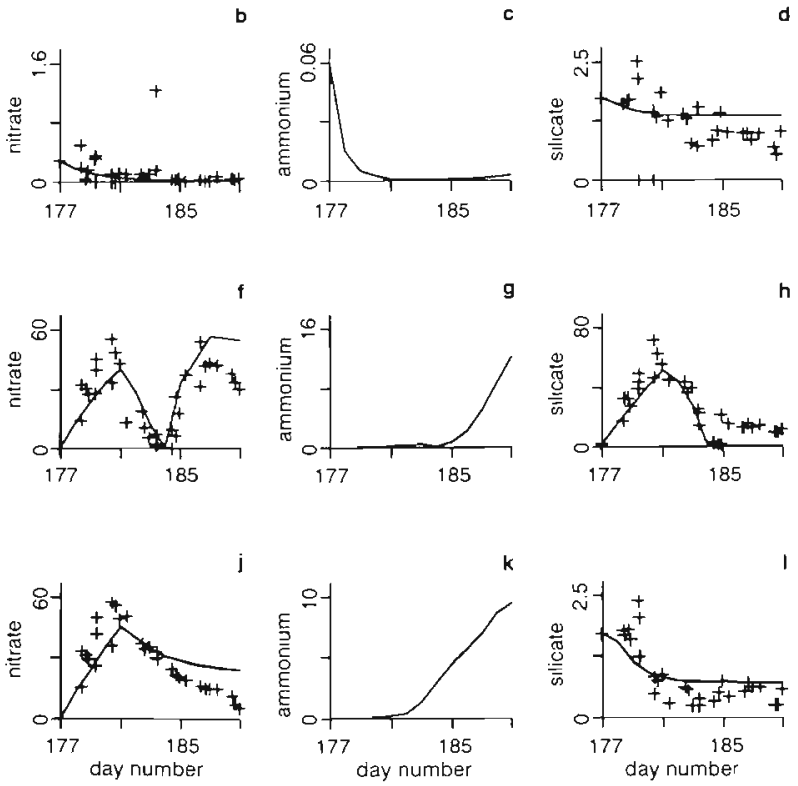

Fig. 6. Simulation output and measurements of the concentrations in mmol m $\mathrm{m}^{-3}$ of inorganic phosphate, nitrate, silicate and ammonium. (a to d) Control enclosure; (e to h) N-, P- and Si-enriched enclosure; (i to l) N- and P-enriched enclosure 


\section{SENSITIVITY ANALYSIS}

The new features in the model described here in comparison with the earlier model (Baretta-Bekker et al. 1994) are (1) the inclusion of the picoalgae and the mixotrophs; (2) the ability of bacteria to take up dissolved inorganic nutrients, instead of only dissolved organic nutrients: (3) the inclusion of luxury uptake, i.e. the ability of the phytoplankters to fill their cells with more nutrients than according to the Redfield ratio; and (4) the decoupling of the nutrient dynamics from the carbon dynamics for the phytoplankton functional groups.

For some of the variables the combined effects of these changes are illustrated in Fig. 7, by comparing results of the standard run of the model described with results of the older model. To test whether the changes in this model were also improvements several tests were carried out.

\section{Inclusion of picoalgae}

The inclusion of picoalgae as an explicit component in the system led to slightly higher regeneration fluxes in all the food web components that are directly or indirectly related to the picoalgae, as well as to slightly higher biomasses of bacteria and their grazers. In general the mean turnover times (Table 8 ) for $P$ and $N$ were lower in the run including picoalgae, indicating that the system runs faster in the presence of picoalgae.

\section{Inclusion of mixotrophic flagellates}

In the standard run the mixotrophs as a functional group were most dominant in the control enclosure, accounting for $49 \%$ of the pigmented biomass and $48 \%$ of the primary production, compared to 11 and $14 \%$, respectively, in the $\mathrm{N}$-, $\mathrm{P}$ - and Si-enriched enclosure and 32 and $26 \%$, respectively, in the $\mathrm{N}$ - and Penriched enclosure. A comparison was made between the standard run and 2 runs where the mixotrophic flagellates were modelled either as exclusively autotrophic or as exclusively heterotrophic. In both sensitivity analyses other functional groups were almost unaffected, except for the picoalgae and the bacteria that reached higher biomasses presumably because of lower grazing pressure. The mixotrophs themselves had lower biomasses than with both nutrition modes, but were doing significantly better as purely autotrophs than as purely heterotrophs. In both cases the primary production stayed almost the same in the nutrient-enriched enclosures, but reached much lower levels in the control enclosure, leading to a $74 \%$ reduction of the total net primary production. Thus the oligotrophic system was the most sensitive to changes in mixotrophic nutrition mode.

\section{Ability of bacteria to take up inorganic nutrients}

N. P, Si-enriched

old version ------
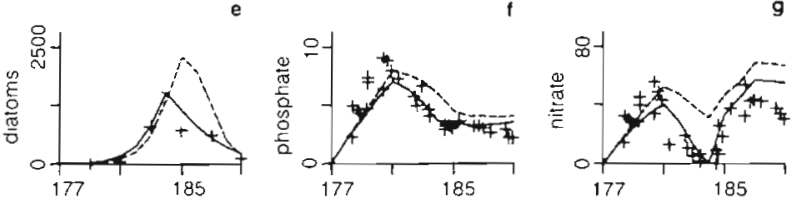

N. P anriched standard
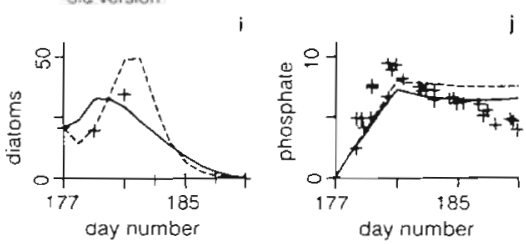

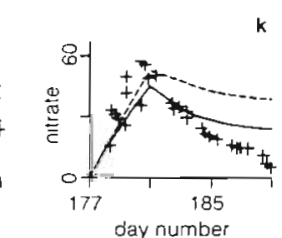
oid version -..---.
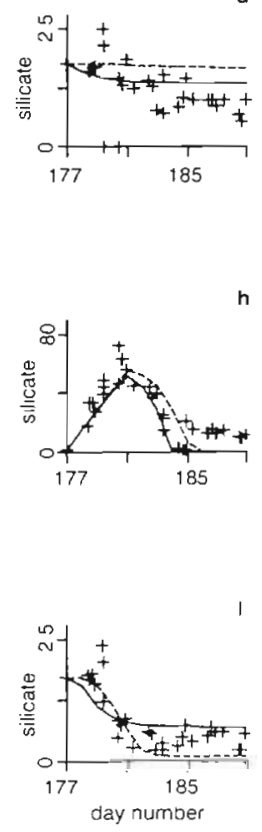

Fig. 7 Simulation output and measurements of the standard model (MEICE) compared to an earlier model version (Baretta-Bekker et al. 1994) (old version)
The main effects of switching off the capability for inorganic nutrient uptake by bacteria could be seen in the primary producers and especially in the picoalgae. The producers benefited from the absence of competitors if bacteria were not taking up nutrients. In the nutrient-enriched enclosures only a small effect on picoalgae could be seen. Considerable effects occurred in the fluxes from picoalgae to mixotrophic and heterotrophic flagellates (Table 9) during the period where the picoalgae could realise a higher growth because of the lack of competition for nutrients. 
Table 8. Normalised turnover times ( $t_{p}$ for phosphorus and $t_{n}$ for nitrogen) for the sensitivity analysis carried out. For the normalisation the value of the turnover times for the standard version is set to 1 . The different runs are indicated: min-P3, without picoalgae; P6-aut, mixotrophs modelled as autotrophs; P6-het, mixotrophs modelled as heterotrophs; min-P3P6, without picoalgae and mixotrophs; nonutB1, without inorganic nutrient uptake by bacteria; nolux, without luxury uptake; nolux-minP3P6, without luxury uptake and without picoalgae and mixotrophs; old version (Baretta-Bekker et al. 1994)

\begin{tabular}{|c|c|c|c|c|c|c|c|c|c|c|}
\hline & Enclosure & Standard & $\min -\mathrm{P} 3$ & P6-aut & P6-het & $\min -P 3 P 6$ & nonutB1 & nolux & $\begin{array}{l}\text { nolux- } \\
\text { minP3P6 }\end{array}$ & $\begin{array}{c}\text { Old } \\
\text { version }\end{array}$ \\
\hline$t_{p}$ & Control & 1 & 1.6 & 1.0 & 1.3 & 2.3 & 3.2 & 1.2 & 2.4 & 232 \\
\hline$t_{p}$ & $\mathrm{~N}, \mathrm{P}, \mathrm{Si}$ & 1 & 1.3 & 0.8 & 1.0 & 1.4 & 1.1 & 1.7 & 1.9 & 3.4 \\
\hline$t_{p}$ & $N, P$ & 1 & 1.5 & 0.8 & 1.0 & 1.8 & 1.0 & 2.2 & 3.6 & 4.8 \\
\hline$t_{n}$ & Control & 1 & 0.8 & 1.6 & 0.9 & 1.0 & 1.5 & 1.0 & 1.0 & 31.7 \\
\hline$t_{n}$ & $\mathrm{~N}, \mathrm{P}, \mathrm{Si}$ & 1 & 1.5 & 0.4 & 0.9 & 0.7 & 0.4 & 1.1 & 1.4 & 1.2 \\
\hline$t_{n}$ & $N, P$ & 1 & 1.5 & 0.9 & 1.2 & 2.0 & 1.0 & 2.7 & 4.5 & 4.0 \\
\hline
\end{tabular}

In the nutrient-enriched enclosures the ability of bacteria to take up inorganic nutrients had no influence on the turnover times of phosphorus (Table 8). In the control enclosure the model system ran considerably slower when the bacteria could obtain their nutrients only from organic sources.

\section{Inclusion of luxury uptake}

The effect of including luxury uptake was tested by comparing the standard run in which the maximal intracellular ratio for all phytoplankton groups was set to twice the Redfield ratio, with a run where the maximal intracellular ratio was halved (equal to the Redfield ratio). No effect could be seen in the control enclosure, but luxury uptake in the nutrient-enriched enclosures resulted in much closer correspondences between the simulated and the observed nutrient concentrations (Fig. 8). With regard to the time evolution of picoalgae with and without luxury uptake the standard value for the capacity for luxury uptake of picoalgae in the model was apparently too high.

The turnover times for phosphorus in the control were not affected by the inclusion of luxury uptake as there could not be luxury uptake under those circumstances. In the nutrient-enriched enclosure the model system with luxury uptake ran much faster than without (Table 8 ).

\section{Decoupling the nutrient and carbon dynamics in the phytoplankton groups}

To test the effect of decoupling the nutrient uptake from the carbon growth dynamics in the phytoplankton functional groups the output of a run with the old formulation for the phytoplankton module (Varela et al. 1995) and the new one was compared. Because the difference between the old formulation and the new one is not just the decoupling, but the fact that the old one is also without picoalgae and mixotrophic flagellates, and without luxury uptake, the comparison was done between the old primary production module and a run with the new primary production module, without picoalgae and mixotrophs, and without luxury uptake.

The role of the decoupling was most evident in the nutrient concentrations in the control enclosure (Fig. 9). In the nutrient-enriched enclosure only small effects could be seen.

In the control decoupling the nutrient from the carbon dynamics made the phosphorus dynamics faster by a factor of 200 and the nitrogen dynamics faster by a factor of 30 (Table 8).

\section{VALIDATION OF THE MODEL}

From the mesocosm experiments carried out in the upper brackish layer of Hylsfjord, Norway, used for the

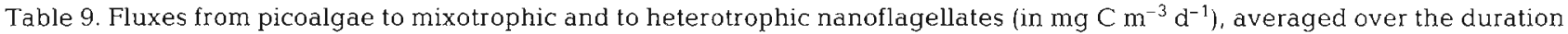
of the experiments, in the 3 enclosures for 2 different runs: the standard run and and a run where the bacteria were not able to take up inorganic nutrients (nonutB1)

\begin{tabular}{|c|c|c|c|c|c|c|}
\hline \multirow[t]{2}{*}{ Run } & \multicolumn{3}{|c|}{ Flux from picoalgae to heterotrophic flagellates } & \multicolumn{3}{|c|}{ Flux from picoalgae to mixotrophic flagellates } \\
\hline & Control & $N, P$ & $\mathrm{~N}, \mathrm{P}, \mathrm{Si}$ & Control & $N, P$ & N, P, Si \\
\hline Standard & 1.25 & 15.21 & 21.25 & 1.26 & 12.95 & 15.73 \\
\hline nonutB1 & 2.72 & 16.25 & 23.47 & 2.35 & 14.76 & 18.10 \\
\hline
\end{tabular}



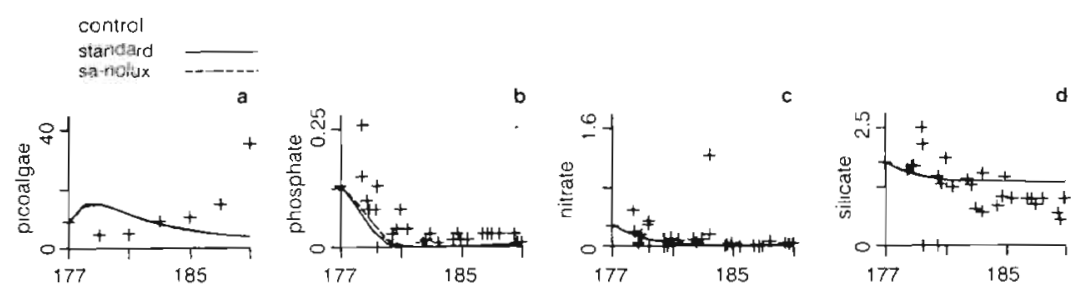

N.P. Si-enriched standard
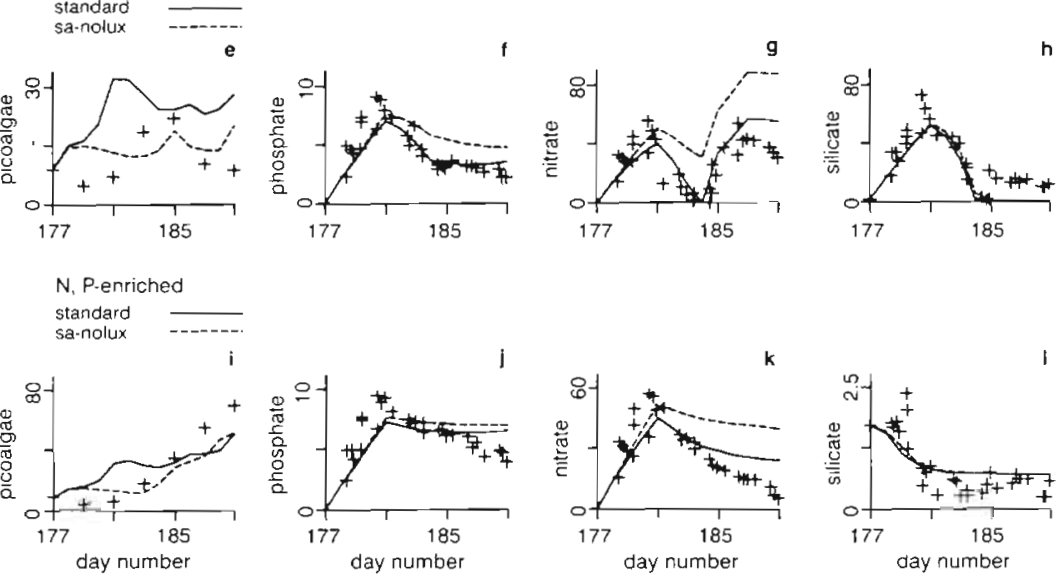

Fig. 8. Simulation output and measurements of the standard model compared to the model with no luxury uptake (sa-nolux) was reproduced by the model accordingly.

The model, using the local initial conditions and physical forcing, but without any reparameterisation or recalibration, satisfactorily simulated the enclosures to which nitrogen and phosphate (NP, NPG) had been added, especially when taking into account the qualitative differences between these systems and those used for calibration (Knebel Vig, Denmark).

In the phosphate-limited enclosures the model did not reproduce the data well. The phosphate concentration and regeneration were underestimated and therefore also the phytoplankton biomass and production were too low (Fig. 10).

\section{DISCUSSION}

There is a continuous flux from dissolved inorganic carbon to particulate organic matter in the pelagic environ-

validation of the model, 4 enclosures to which nitrogen $(\mathrm{N})$ and/or phosphate (NP) and/or glycine (NG, NPG) had been added were simulated (see Table 2). Nitrogen was added to all enclosures to avoid a shift to nitrogen limitation under the assumption that the experimental system was phosphate-limited. Glycine was added to test whether bacteria were carbonlimited.

The validation could be done only partly, because in the Hylsfjord there were no unmanipulated enclosures to use as control, Using the open fjord as control was not realistic because of the very different hydrodynamic conditions in the enclosures and the open fjord. The mixotrophic flagellates could not be included as an active functional group since no bacterivorous mixotrophic flagellates were identified in the enclosures.

The data did not show any significant difference between enclosures to which glycine (NG, NPG) had been added and those without glycine (N, NP) (Havskum \& Hansen 1997). This
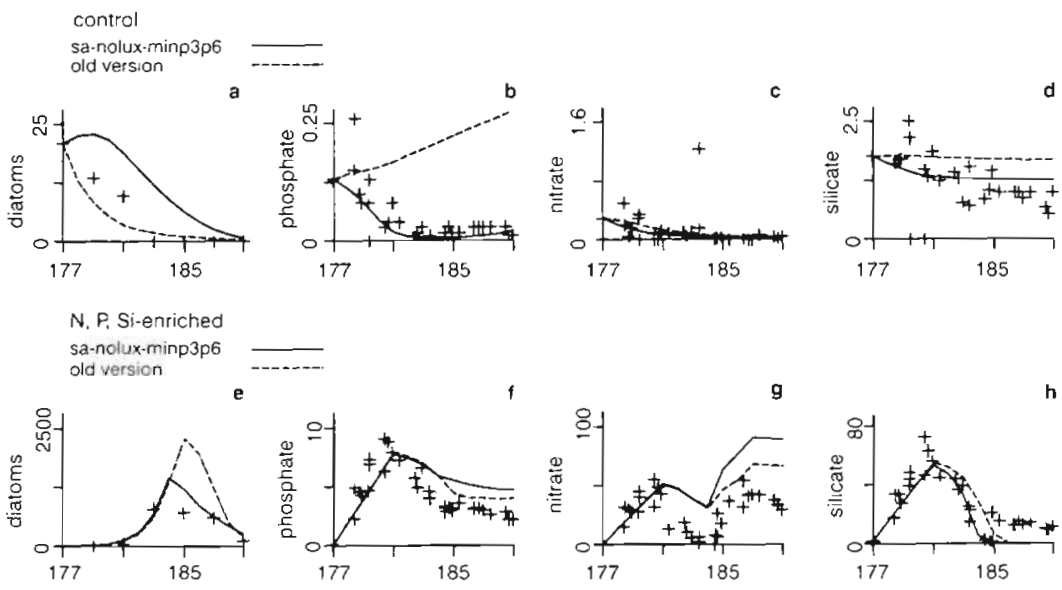

N. P-enriched s: Aa-nolux-ming3p6 old version
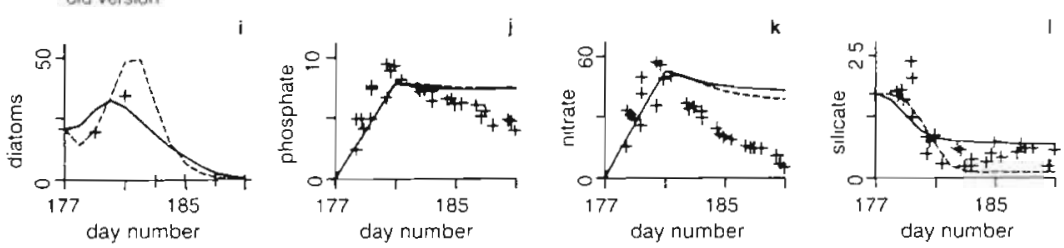

Fig. 9. Simulation output and measurements of the standard model without luxury uptake, without picoalgae and without mixotrophs (sa-nolux-minp3p6) compared to an earlier model version (Baretta-Bekker et al. 1994) (old version) 

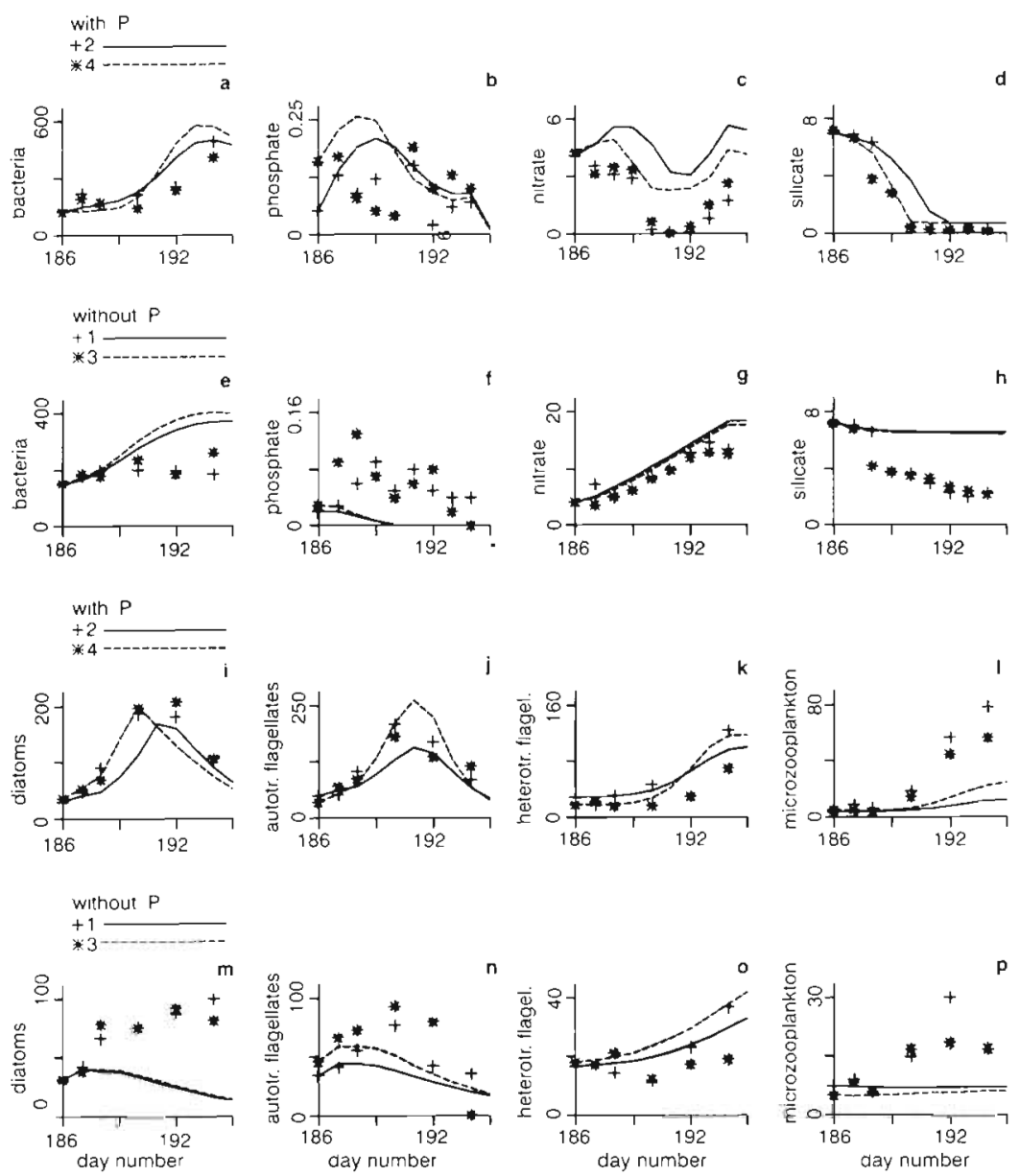

Fig. 10. Simulation output and measurements of the Norway mesocosms, with phosphate $(2,4)$ and without phosphate $(1,3) .(+)$ With glycine; $(*)$ without glycine

ment. The trophic pathways of this material vary widely, ranging from the traditional food web (Cushing 1989) with organic matter going from large phytoplankton, mainly diatoms, to zooplankton to fish to top predators, to a microbial loop at the other end. These disparate food webs are often seen as discontinuous and mutually exclusive. Legendre \& Rassoulzadegan (1995), however, argued that the traditional food web at the one end and the microbial loop at the other are unstable extremes on a trophic continuum.

A major difference between the systems is in the relative contribution of the biological components to carbon and nutrient cycling which in turn is dependent on a set of interacting physical and biological conditions (Fig. 1 in Legendre \& Rassoulzadegan 1995)

The model described here reproduced different instances of this food-web continuum. The time-averaged carbon and phosphorus budgets (Figs. 1 \& 2) for the different enclosures extracted from the model results showed the carbon and phosphorus fluxes through the smallest components in the model to be far larger than through the micro- and mesozooplankton in all enclosures. The absolute sizes of the fluxes were different in all enclosures, but also the normalised fluxes, which were directly comparable, gave different patterns in the control enclosure and the nutrient-enriched enclosures. In the control enclosure respiratory processes dominated the trophic transfer fluxes, with the exception of DOC uptake by bacteria. In the nutrientenriched enclosures, especially in the $N$ - and P-enriched one (Fig. 1c), the trophic transfer fluxes, especially from phytoplankton, were much higher and the DOC recycling by bacteria relatively lower.

Calculating the ratios between the time-averaged total grazing flux from the autotrophs (including the autotrophic part of the mixotrophs) and the grazing flux from bacteria to the heterotrophs (including the heterotrophic part of the mixotrophs) gave $0.4,1.0$ and 2.0 for the control, the $N$, $\mathrm{P}$ and Si enclosure and the $\mathrm{N}$ and $\mathrm{P}$ enclosure, respectively. This suggests that the relative importance of the fluxes through the bacteria was largest in the control, and that the relative importance of the direct fluxes from the phytoplankton groups to the heterotrophic groups was largest in the $\mathrm{N}$ and $\mathrm{P}$ enclosure. The N, P and Si enclosure occupied an intermediate position. The time-averaged carbon budgets put the control enclosure close to one end of the food-web continuum and the $\mathrm{N}$ - and $\mathrm{P}$-enriched enclosure close to the other extreme. In the N, P and Si enclosure halfway through the experiment there was a shift from a nutrient-enriched to a nitrogen-limited situation for a few days, modifying this enclosure from a system with complete nutrient availability to a system with unbalanced nutrient availability. These changing conditions changed the position of this enclosure on the continuum, resulting in a time-averaged situation that was somewhere between the control and the $\mathrm{N}$ - and $\mathrm{P}$ enriched situation. Calculating the ratio between the time-averaged sum of the fluxes from autotrophs to heterotrophs and the fluxes via bacteria to heterotrophs averaged over the first part of the experiment (Days 1 to 7 ) gave a value of 3.25 for the N, P and Si enclosure. Until the sudden occurrence of a tempo- 
rary nitrogen limitation the $\mathrm{N}, \mathrm{P}$ and $\mathrm{Si}$ enclosure was thus situated further towards the classical food web than the $\mathrm{N}$ and $\mathrm{P}$ enclosure.

The model-derived $\mathrm{P}$ budgets clearly indicate the central role of the microbial loop in recycling phosphorus in an oligotrophic situation (Fig. 2a). The P budgets also show the competition between bacteria and phytoplankton for inorganic phosphorus. In the control $59 \%$ of the total inorganic phosphorus taken up went to the bacteria, while in the $\mathrm{N}$-, $\mathrm{P}$ - and $\mathrm{Si}$ - and $\mathrm{N}$ - and P-enriched enclosures it was the phytoplankton groups that took up most of the inorganic phosphorus, 91 and $96 \%$ respectively. In all enclosures most of the recycling $[81,67$ and $55 \%$ of the total phosphorus (inorganic phosphorus plus dissolved organic phosphorus) in the control, $\mathrm{N}, \mathrm{P}$ and $\mathrm{Si}$, and $\mathrm{N}$ and $\mathrm{P}$ enclosures, respectively] was directed to the dissolved organic phosphorus available only to bacteria.

The decoupling of the nutrient and carbon dynamics led in nutrient-limited situations to excretion of nutrient-poor organic carbon (polysaccharides) by phytoplankton. In combination with the ability of bacteria to take up inorganic nutrients when DOM is nutrientpoor, in the model this had the effect that bacteria now may compete with the phytoplankton for nutrients. As a consequence the role of the bacteria changed with the nutrient availability. In the control enclosure bacteria functioned as a nutrient sink, shifting nutrient regeneration to the bacterial predators. The predation on bacteria by heterotrophic nanoflagellates and mixotrophic flagellates, regenerating nutrients and controlling the biomass of bacteria, allowed for the coexistence of algae and bacteria, even though the bacteria are more efficient competitors for nutrients (Thingstad \& Pengerud 1985, Thingstad 1992). In the nutrient-rich situations, the excretion flux of dissolved organic carbon, which here is mainly generated by the heterotrophs, lowered the direct uptake of inorganic nutrients by bacteria to insignificance (Fig. 2b, c). The bacteria were net nutrient mineralisers in these situations, but the other heterotrophs were still more important as mineralisers. In the validation enclosure in Hylsfjord, Norway, the addition of glycine had no effect on bacteria neither in the measurements nor in the model (Thingstad pers. comm.) This confirms that the bacterial production in some situations can be nutrient-limited instead of carbon-limited, and that the ecosystem response to additions of organic matter depends on the composition of the addition as well as on the nutrient status of the ecosytem (Thingstad 1992)

The mixotrophic flagellates were a new functional group in this model. The sensitivity analysis suggested that the possibility of 2 different carbon sources was not crucial for modelling the rest of the variables.
When mixotrophs were modelled as either heterotrophs or autotrophs, their biomass remained low, and the biomasses of their prey organisms increased. The most sensitive variable was, however, the primary production in the control enclosure, where the mixotrophs modelled as autotrophs or heterotrophs led to a $74 \%$ reduction in community primary production, compared to the standard mixotrophs with 2 nutrition modes. This indicates that the mixotrophic pathway of nutrients from bacteria gave an important flow of nutrients that allowed use of more of the carbon produced by photosynthesis. This not only gave the mixotrophs a competitive advantage, but increased the total productivity of the system and implied that inclusion of the mixotrophic flagellates in fact is essential for correct estimations of primary production in nutrient-limited systems where they might contribute significantly more to primary production than in nutrient-rich systems. In the standard run the mixotrophs contributed most to the primary production (48\%) and pigmented biomass $(49 \%)$ in the control enclosure. This is in accordance with Havskum \& Riemann (1996) who found that mixotrophic flagellates accounted for $49 \%$ of the pigmented biomass in a nutrient-depleted upper layer of the Bay of Aarhus, but only $9 \%$ of the pigmented biomass in the nutrient-rich water below the pycnocline. There was a significant difference in bacterial abundance, however, which was low $\left(<10^{9} \mathrm{dm}^{-3}\right)$ above and higher $\left(>10^{9} \mathrm{dm}^{-3}\right.$ ) below the pycnocline, suggesting that the difference in the role of mixotrophs partly could be explained by increased competition with the strict heterotrophs in the bacteria-rich lower layer. The rate of phagotrophy for some species, especially mixotrophic flagellates that rely primarily on photosynthesis, is controlled by the nutrient level, whereas particle density controls the nutrition mode for other more phagotrophic species (Riemann et al. 1995).

The mixotrophic contribution to the total grazing on bacteria was around $40 \%$ in all 3 enclosures (Fig. 1), indicating that the rate of phagotrophy was not controlled by the nutrient level in the model. The factors controlling the mixotrophs' nutrition mode in the model were light, which controlled gross primary production, and nutrients, which controlled net primary production through nutrient-stress excretion.

The changes in respect to the previous version of the model (Baretta-Bekker et al. 1994) have improved the nutrient dynamics considerably, as can be seen in Fig. 7. These changes included the inclusion of luxury uptake, the decoupling of nutrient from carbon dynamics in the phytoplankton, and the possibility for bacteria to take up inorganic nutrients directly. Luxury uptake improved the model results in the enriched enclosures (Fig. 9). Both the time evolution of the inor- 
ganic nutrients and the nutrient turnover times came much closer to the observations. The decoupling of nutrient and carbon dynamics in the primary producers was the mechanism responsible for the improvements in the control enclosure (Fig. 10). The effect of this mechanism is that the dissolved organic carbon excreted under nutrient stress (the control enclosure) now is nutrient-poor, driving the bacteria into direct nutrient uptake and thus into competing for nutrients with the phytoplankton, shifting the role of net mineralisers to the bacterial grazers.

The validation with enclosures from Hylsfjord, Norway, indicated that the evolution of a nutrientenriched system is well captured by the model. The addition of an organic carbon/nitrogen source (glycine) which was not added in Knebel Vig gave model results in accordance with the experiments (Thingstad pers. comm.). The strongly phosphate-depleted enclosures were, however, not predicted well by the model, indicating that this situation was more nutrient-limited than the control in Knebel Vig. Thus there seems to be a lack of understanding of the dynamics in strongly limited systems, which leaves room for further improvements of the description of the nutrient dynamics in planktonic food webs. Important aspects to be tested are the description of a bacterial nutrient limitation and bacterial death by viral lysis (Bratbak et al. 1992, Thingstad pers. comm.).

An overall problem in the model described is the grazing interactions dependent on the nutrient condition of the system. In particular, the consequences of grazers not being able to handle all forms (e.g. filamentous bacteria) in which their prey may occur equally well, which may lead to rapid increases in abundance of 'inedible' forms, cannot be accounted for by present models.

\section{CONCLUSIONS}

Dynamic simulation models, like the one used here, are far from perfect, reflecting our incomplete understanding of the nutrient dynamics in strongly nutrientlimited environments and of the grazing interactions in the small food web and their consequences to food web structure and dynamics. Major biomass compartments in planktonic food webs and fluxes of carbon and nutrients can nevertheless be predicted. The decoupling of carbon and nutrient dynamics and the inclusion of nutrient luxury uptake into the modified model approach presented here gave a better model description of the nutrient fluxes than previous versions (Baretta-Bekker et al. 1994). In addition, the idea that mixotrophy is a proper feeding strategy in strongly nutrient-depleted environments and that it also allows for the coexistence of pigmented organisms with bacteria was confirmed. Both the model predictions presented here and experimental results (Havskum et al pers. comm.) demonstrated that mixotrophic flagellates, in the environments examined here, constituted a significant link in the carbon and phosphorus budgets. Mixotrophic flagellates were responsible for more than $40 \%$ of the grazing of bacteria in the model, and model predictions suggested that mixotrophy leads to increased primary production in the nutrientlimited enclosures compared to a situation with a strict photoautotrophic nutrition mode. The model successfully described a generic pelagic food web with dynamically changing pathways of carbon and nutrients which expanded or contracted in response to changes in the nutrient regimes, changing the relative importance of the classical food web and the microbial food web.

Acknowledgements. This study was partly funded by the European Union through MAST If contract MAS2-CT92-0031 for J.G.B.-B. and B.R. For J.W.B. this study was supported by the EU MAST II program, contract MAS2-CT92-0032. The authors thank all the participants of the MEICE project, who made available data from the mesocosm experiments to be used in this model: Torkel Gissel Nielsen for the mesozooplankton and microzooplankton data; Hanne Kaas for the nutrient data and the data on $\mathrm{NH}_{4}$ regeneration; Harry Havskum and Winnie Martinsen for bacteria and phytoplank-

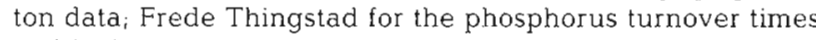
and for his helpful comments on an earlier version of the manuscript

\section{LITERATURE CITED}

Baretta JW, Ebenhöh W, Ruardij P (1995) The European Regional Seas Ecosystem Model, a complex marine ecosystem model. Neth J Sea Res 33:261-270

Baretta-Bekker JG, Baretta JW, Ebenhöh W (1997) The microbial food web in the European Regional Seas Ecosystem Model with decoupled carbon and nutrient dynamics. Neth J Sea Res 38(3/4) (in press)

Baretta-Bekker JG, Baretta JW, Rasmussen EK (1995) The microbial food web in the European Regional Seas Ecosystem Model. Neth J Sea Res 33:363-379

Baretta-Bekker JG, Riemann B, Baretta JW, Rasmussen EK (1994) Testing the microbial loop concept by comparing mesocosm data with results from a dynamical simulation model. Mar Ecol Prog Ser 106:187-198

Bennett SJ, Sanders RW, Parker KG (1990) Heterotrophic, autotrophic, and mixotrophic nanoflagellates: seasonal abundances and bacterivory in a eutrophic lake. Limnol Oceanogr 35:1821-1832

Bird DF, Kalff J (1986) Bacterial grazing by planktonic lake algae. Science 231:493-495

Blackburn N, Zweifel UL, Hagström $\AA$ (1996) Cycling of marine dissolved organic matter II. A model analysis. Aquat Microb Ecol 11:79-90

Bratbak G, Heldal M, Thingstad FT, Riemann B, Haslund $O H$ (1992) Incorporation of viruses into the budget of microbial C-transfer, A first approach. Mar Ecol Prog Ser 83: $273-280$ 
Broekhuizen N, Heath MR, Hay SJ, Gurney WSC (1995) Modelling the dynamics of the North Sea's mesozooplankton. Neth J Sea Res 33:381-406

Cushing DH (1989) A difference in structure between ecosystems in strongly stratified waters and in those that are only weakly stratified. J Plankton Res 11:1-13

Droop MR (1974) The nutrient status of algal cells in continuous culture. J Mar Biol Assac UK 54:825-855

Ebenhoh W, Baretta-Bekker JG, Baretta JW (1997) The primary producer module in the marine ecosystem model ERSEM. J Sea Res 38(3/4) (in press)

Escaravage V, Peperzak L, Prins TC, Peeters JCH, Joordens JCA (1995) The development of a Phaeocystis bloom in a mesocosm experiment in relation to nutrients, irradiance and coexisting algae. Ophelia 42:55-74

Escaravage V, Prins TC, Smaal AC, Peeters JCH (1996) The response of phytoplankton communities to phosphorus input reduction in mesocosm experiments. J Exp Mar Biol Ecol 198:55-79

Fenchel T (1988) Marine plankton food chains. Ann Rev Ecol Syst 19:19-38

Havskum H, Hansen AS (1997) Importance of pigmented and colourless nano-sized protists as grazers on nanoplankton in a phosphate-depleted Norwegian fjord and in enclosures. Aquat Microb Ecol 12:139-151

Havskum H, Riemann B (1996) Ecological importance of bacterivorous, pigmented flagellates (mixotrophs) in the Bay of Aarhus, Denmark. Mar Ecol Prog Ser 137:251-263

Jørgensen SE (1995) State of the art of ecological modelling in limnology. Ecol Model 78:1.01-115

Editorial responsibility: Frede Thingstad,

Roskilde, Denmark
Legendre L, Rassoulzadegan F (1995) Plankton and nutrient dynamics in marine waters. Ophelia 41:153-172

Nyholm $N$ (1977) Kinetics of nitrogen-limited algal growth. Water Quality Institute, Denmark, p 347-358

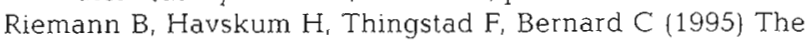
role of mixotrophy in pelagic environments. In: Joint I (ed) Molecular ecology of aquatic microbes. NATO ASI Series G38. Springer-Verlag, Berlin/Heidelberg, p 87-11.4

Ruardij P, Baretta JW, Baretta-Bekker JG (1995) SESAME, Software Environment for Simulation and Analysis of Manine Ecosystems in general and for spatially resolved ecosystems in particular. Neth J Sea Res 33:261-270

Sanders RW (1991) Mixotrophic protists in marine and freshwater ecosystems. J Protozool 38:76-81

Thingstad TF (1992) Modelling the microbial food web structure in pelagic ecosystems. Arch Hydrobiol Beih 37: $111-119$

Thingstad TF, Havskum H, Garde K, Riemann B (1996) On the strategy of 'eating your competitor' A mathematical analysis of algal mixotrophy. Ecology 77(7):39-49

Thingstad TF, Pengerud B (1985) Fate and effect of allochthonous organic material in aquatic microbial ecosystems. An analysis based on chemostat theory. Mar Ecol Prog Ser 21:47-62

Varela RA, Cruzado A, Gabaldón JE (1995) Primary production. Neth J Sea Res 33:337-361

Zweifel UL, Blackburn N, Hagström $\AA$ (1996) Cycling of marine dissolved organic matter. 1. An experimental system. Aquat Microb Ecol 11:65-77

Submitted: November 1, 1996; Accepted: July 30, 1997 Proofs received from author(s): November 18, 1997 